\title{
Analyze Education and Training Using Marine Engine Simulator at Stip Jakarta Indonesia
}

\author{
A Rachman', M Simanjuntak ${ }^{2}$ \\ \{Abdulrachman_agbstip@yahoo.co.id ${ }^{1}$ \} \\ ${ }^{1,2}$ STIP (Sekolah Tinggi Ilmu Pelayaran) Jakarta, Indonesia
}

\begin{abstract}
On this research paper analysis Cadet Engineer, junior engineer, Operational level senior engineer, and management level senior engineer will do an experiment using data velocity various scenario at marine engine simulator and then result of experiment will use analysis education and training marine engine simulator for to know correct time. Then analysis has also revealed that the human errors occur for the following reasons: Lack of knowledge on the overall system and fundamental operation, insufficient confirmation to operation and incomplete knowledge on the operational sequence. the roles of instructor will be described in order to reduce the cause for such human errors and to enhance the educational performance according implemented and development each them various scenario base on expert justification and reference IMO Standard and SOLAS. kinds various scenario safety procedure for all Engineer with hope to minimalist accident loss of soul at sea. For the purpose of machinery plant operation training by means of Engine Room Simulator (ERS) based on PC, describes the features of human errors by the Incompetence trainees in the marine engine plant operation and shows the necessary improvement in the training in order to decrease such errors from the viewpoint of educational technology. The examination of such data has shown that error occurs mainly by omission error and extraneous act. Further analysis was made on such errors by the trainees' engineer to find out the characteristics of errors caused in the process of acquiring procedural knowledge for the operation according implemented development various safety scenario.
\end{abstract}

Keywords: Cadet Engineer, Marine engine simulator, STIP Jakarta Indonesia

\section{Introduction}

Mulbyantoro [1]According data from National Transportation Safety National (NTSC), From year 2010 until Year 2016 increasing which accident sea transportation, Cause of sinking of the ship, ship Collision or ship Burned. During range of this years, number 658 people die and 568 people injury, Cause of accident is technical problem number $51 \%$ and $49 \%$ cause by human error.[2]

Trethewey [3]Data marine vessel accidents were investigated NTSC (source: Database NTSC up to December 27, 2016)[4] 


\begin{tabular}{|c|c|c|c|c|c|c|c|}
\hline \multirow{2}{*}{ No. years } & \multirow{2}{*}{$\begin{array}{l}\text { Number Of } \\
\text { Accidents }\end{array}$} & \multicolumn{4}{|c|}{ Accidents } & \multicolumn{2}{|c|}{ Fatalities } \\
\hline & & Sinking ship & $\begin{array}{l}\text { Ship Burned / } \\
\text { Exploded }\end{array}$ & $\begin{array}{c}\text { Ship } \\
\text { Collision }\end{array}$ & $\begin{array}{c}\text { Ship } \\
\text { Grounded }\end{array}$ & $\begin{array}{l}\text { Deceased / } \\
\text { Missing }\end{array}$ & wounded \\
\hline 2010 & 4 & 1 & 1 & 3 & 0 & 100 & 104 \\
\hline 2011 & 6 & 1 & 3 & 2 & 0 & 10 & 51 \\
\hline 2012 & 4 & 0 & 2 & 2 & 0 & 447 & 0 \\
\hline 2013 & 6 & 2 & 2 & 2 & 0 & 15 & 85 \\
\hline 2014 & 7 & 2 & 3 & 2 & 0 & 86 & 346 \\
\hline 2015 & 11 & 3 & 4 & 3 & 1 & - & - \\
\hline 2016 & 11 & 4 & 4 & 3 & 0 & 2 & 2 \\
\hline Total & 53 & 13 & 19 & 17 & 1 & 662 & 590 \\
\hline
\end{tabular}

Table 1NTSC Data

Musnasir [5]Therefore need gave Recommendation to all stakeholder for minimizing occur accident sea transportation. During this learning process analysis using for evaluation education and training marine engine simulator all Cadet engine, junior engineer, operational level senior engineer, and Management level Senior engineer using data velocity in doing various development scenario according them each level base on expert justification [6]with reference IMO standard and STCW.

The operational knowledge on the marine engine plant, which is a part of the duty of marine engineer, is procedural knowledge necessary for the smooth operation of the machinery. The unskilled trainee has to acquire such knowledge by actual operating experience on board or by educational training. Since the unskilled trainee are assumed to make a lot of human errors, OJT (On the Job Training) which is the training on the actual operation of the marine engine plant, would be a risky selection. The simulator training is a safe training that never damages machinery and others and, therefore, is effective in learning fundamental knowledge on the machinery operation before starting of the OJT. The content also involves a presentation of how Studying skill Development Resource management is implemented in Marine Engine Simulator include Demonstrated Integrated Engine Marine Resource Management.

In the simulator training, the operational behavior of the trainee, or operational procedure of the trainee until he makes the machinery to a certain state, is recorded as data for an easy review. 
Checking such operational procedure from the point of operational error will be helpful for the instructor to know how the machinery should be operated to the trainee, what are the necessary or unnecessary knowledge for operation and whether the instructor's know-how is appropriated or not. The reason that this paper remarks to the unskilled trainee is because their experience level is low and therefore the effect of simulator training can be found without being affected by actual experienced knowledge. On this Research Cadet Engineer, junior engineer. operational level senior engineer and management level senior engineer will do experiment using data velocity scenario at marine engine simulator. and then Result of experiment will use analysis education and training marine engine simulator for to know correct time according each them scenario base on expert justification and reference IMO Standard and SOLAS. Then analysis education and training using marine.

Engine simulator has also revealed that human errors occur for the following reasons:

Lack of knowledge on the overall system and fundamental operation, Teamwork Preparation \& Coordination, Less Compact team (between semesters. VIII and IV),Lack of

\begin{tabular}{|l|l|l|l|l|l|l|l|l|}
\hline \multirow{2}{*}{ No } & \multirow{2}{*}{ Activity Review } & \multicolumn{6}{|l|}{ Month } \\
\cline { 3 - 9 } & & 1 & 2 & 3 & 4 & 5 & 6 & 7 \\
\hline
\end{tabular}

Motivation(especially semester .IV),Implementation of Scenario,Less effective in equipment familiarization,Insufficient confirmation to operation,Not carefully in reading the instruction,Lack of Support from other teacher,Incomplete knowledge on the operational sequence, Weak attitude and behavior in team and desire to work together 


\begin{tabular}{|l|l|l|l|l|l|l|l|}
\hline 1 & Training preparation & & & & & & \\
\hline 2 & $\begin{array}{l}\text { Training implementation and } \\
\text { Assesment }\end{array}$ & & & & & & \\
\hline 3 & $\begin{array}{l}\text { Training implementation and } \\
\text { Assesment }\end{array}$ & & & & & & \\
\hline 4 & $\begin{array}{l}\text { Training implementation and } \\
\text { Assesment }\end{array}$ & & & & & \\
\hline 5 & Reports Resulth and evaluation & & & & & & \\
\hline
\end{tabular}

Table 2 TIME FRAME RESEARCH JANUARY-JULY 2018

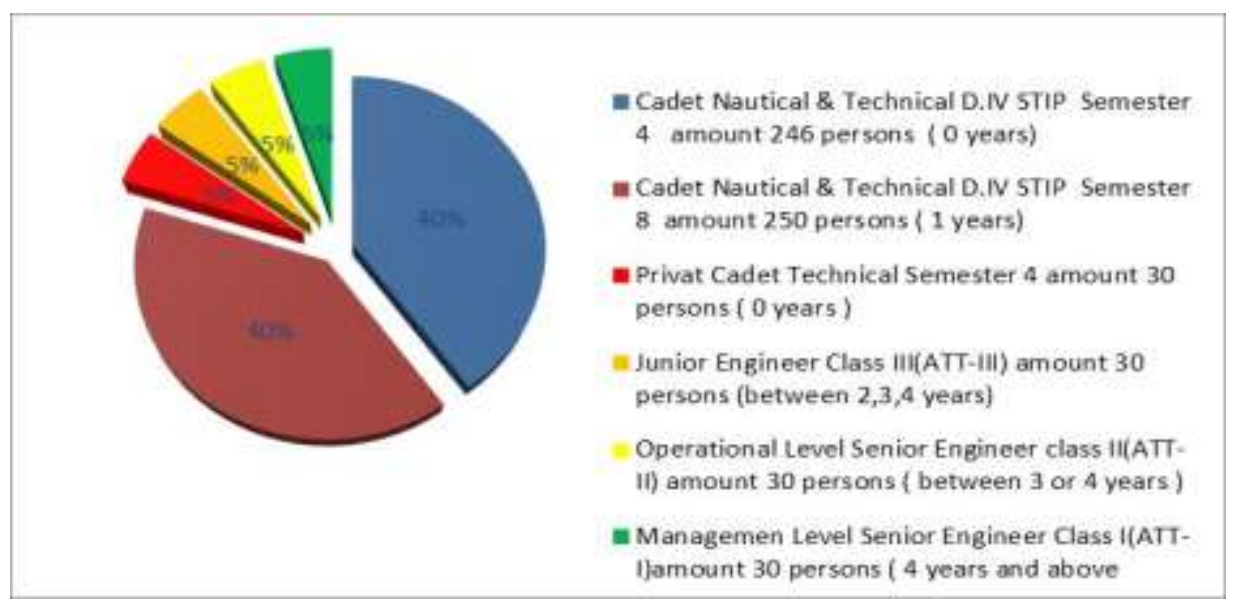

Figure 1respondent Profile

Main issues Private Cadet Engineer, ATT III, ATT II \& ATT I. Lack of knowledge on the overall system and fundamental operation. Insufficient confirmation to operation Incomplete knowledge on the operational sequence teamwork preparation \& coordination: 1) Less compact team ( Between Smt. VIII and IV ),Lack of motivation (especially Smt.IV) 2) Implementation of Scenarios,Less effective in equipment familiarization,Not careful in reading the instructions,Lack of support from other teachers. 
Risk: The achievement of the agreement did not happen as scheduled, Nonconformity of personnel criteria, The lack of attention to the value or the existing system in the industry will not be in accordance with maritime industrial conditions

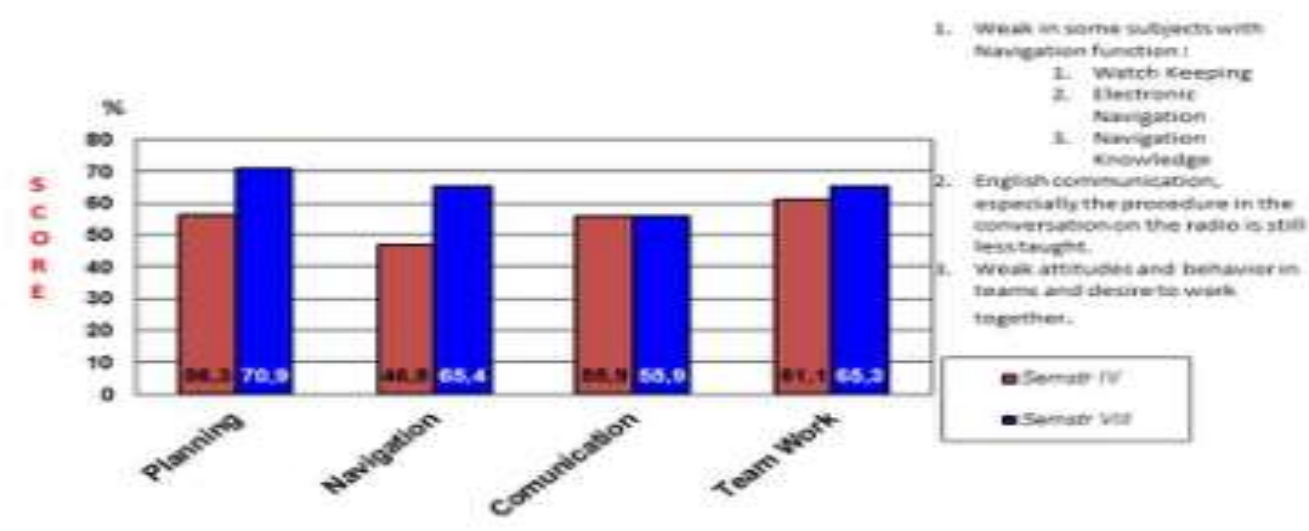

Figure 2 Scope Problem Nautical Department

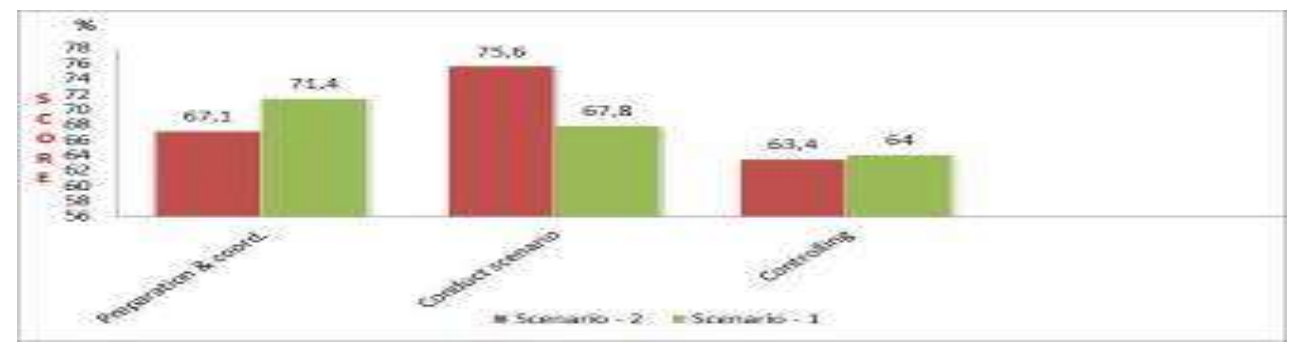

Figure 3Scope Problem Technical Department

The Purpose of this Paper is to elaborating analysis Examine result in implemented various safety scenario and integrated bridge engine simulation studying practice and evaluate whether basic knowledge, operating and management level skill achieved by training in Marine engine simulator Computer base training could be transferred to the operating in engine simulator for to know the correct time.

\section{Literature review}

The syllabus for Simulator Instructor Courses, as given by Prof. Muirhead, was as follows:STCW 95 and the use of simulators,Competency based training,Training process, The role of instructor,Course design,Exercise development,Pre-briefing techniques,Simulator Familiarization,Monitoring and recording activity,DE-briefing techniques and 
feedback,Assessment process, The role of assessor,Feedback and performance evaluation, Validation.

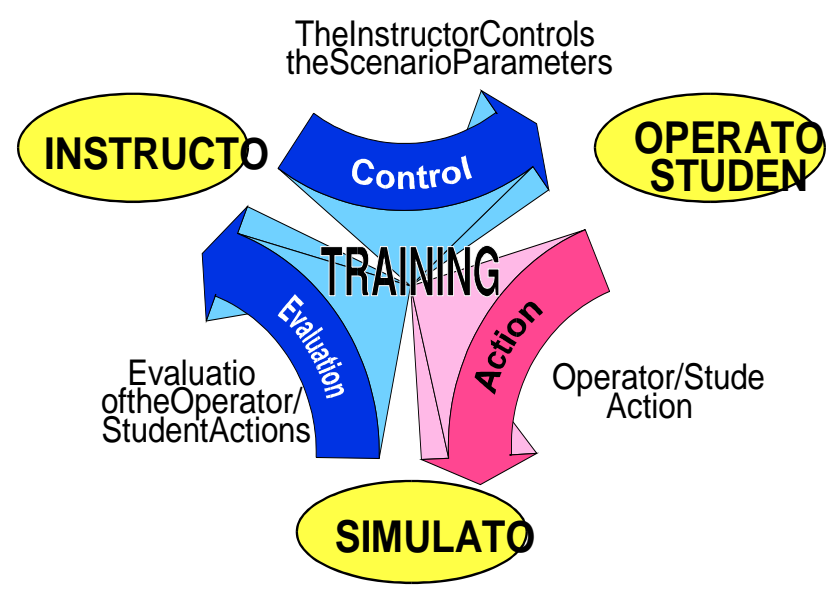

Figure 4 the instructor conrols the scenario prameters

\section{Method}

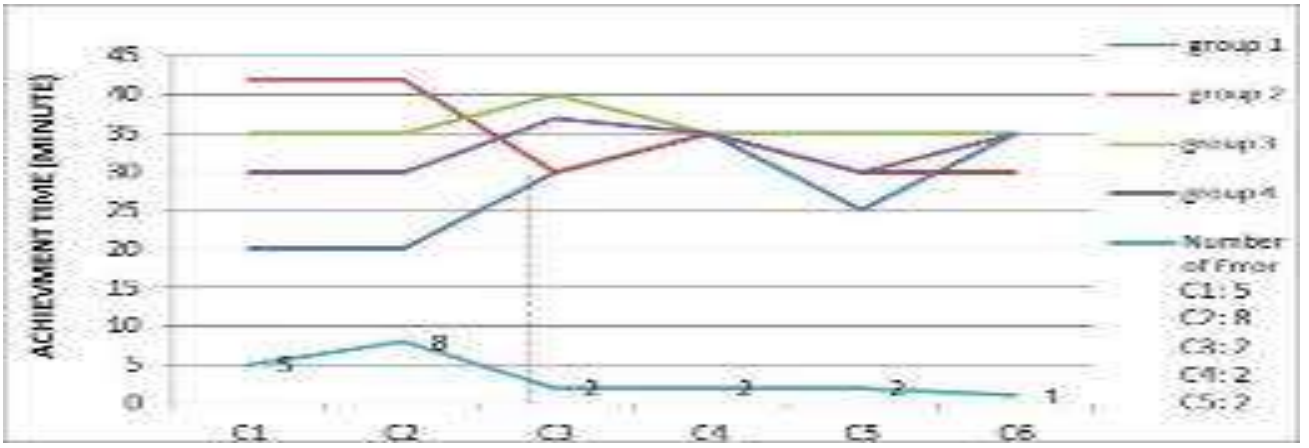

Figure 5Chart Evaluation Pre-Assessment: Private Cadet Engine Simulator Program February 2018 


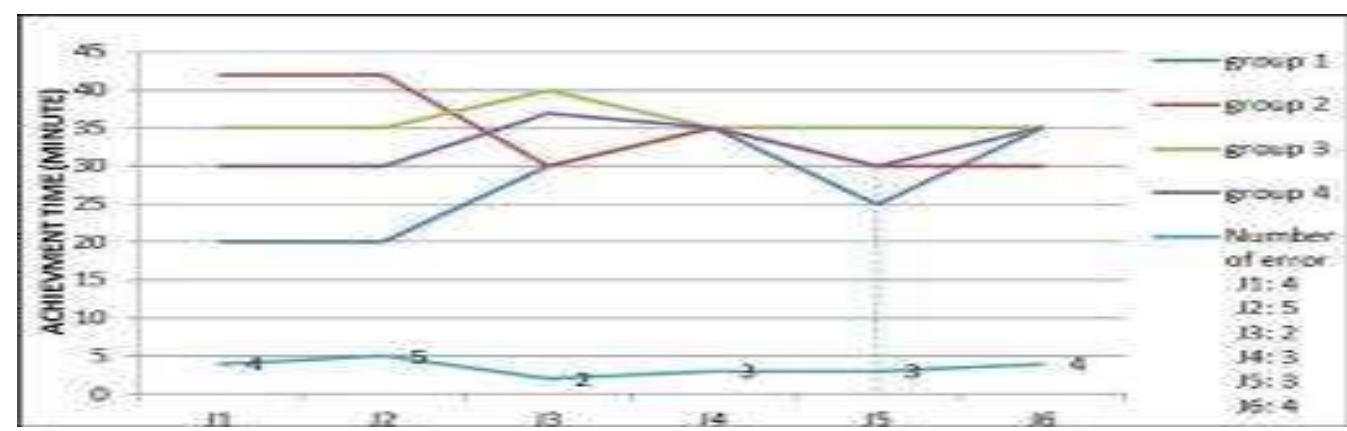

Figure 6 Chart Evaluation Pre-Assessment: Junior Engineer/Att-Iii (Stip) Engine Simulator Program March 2017

Engine Simulatorprogram March 2017

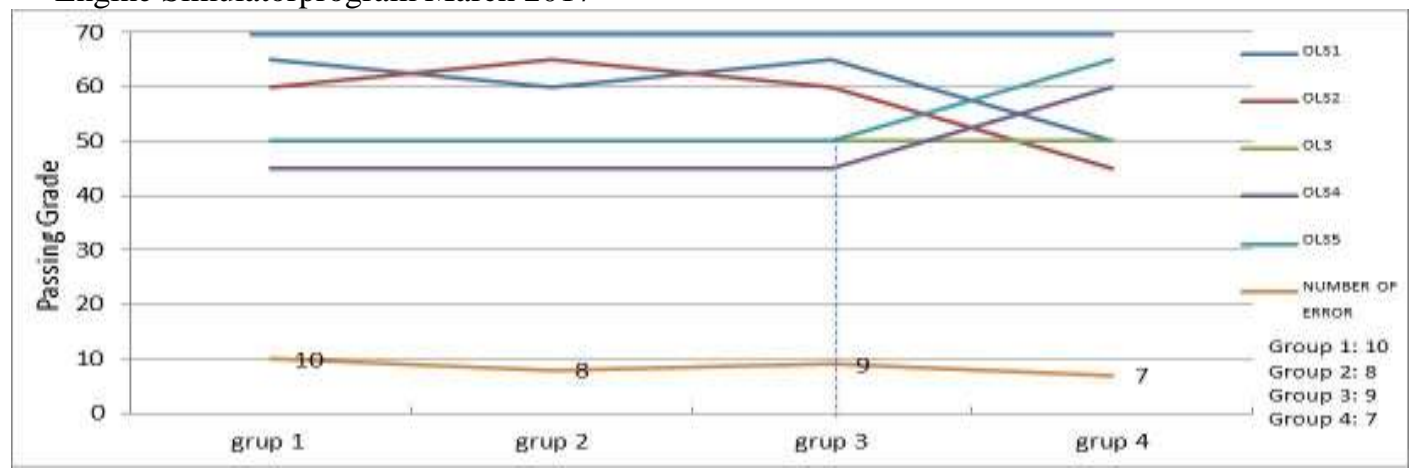

Figure 7figure6chart Evaluation Pre-Assessment: Opersional Senior Engineer/Att-Ii (Stip)

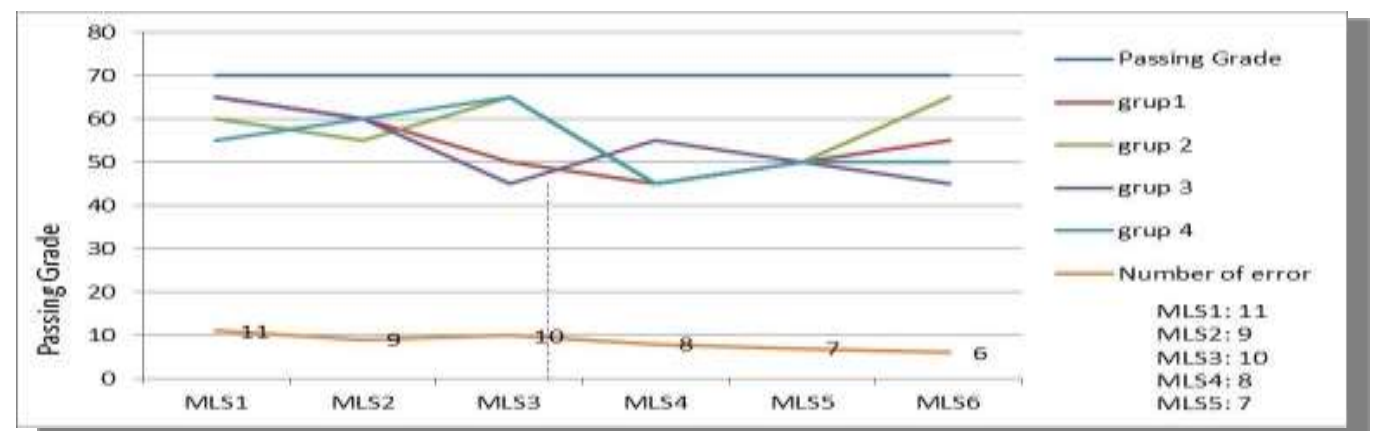

Figure 8 Chart Evaluation Pre - Assessment: Management Senior Engineer/Att-I (Stip) Engine Simulator Program June 2017 


\section{Result and Discussion}

\begin{tabular}{|c|c|c|c|c|c|c|}
\hline JUNIOR engineer & time standard & $\begin{array}{l}\text { group } \\
1\end{array}$ & $\begin{array}{l}\text { group } \\
2\end{array}$ & $\begin{array}{l}\text { group } \\
3\end{array}$ & $\begin{array}{l}\text { group } \\
4\end{array}$ & $\begin{array}{l}\text { Number } \\
\text { of error }\end{array}$ \\
\hline $\begin{array}{l}\text { 1: Scenario for preparing for getting } \\
\text { underway }\end{array}$ & 30 minute & $20 \mathrm{~min}$ & $42 \mathrm{~min}$ & $35 \mathrm{~min}$ & 30min & 4 \\
\hline Scenario for manouvering to open sea & 30 minute & $20 \mathrm{~min}$ & $42 \mathrm{~min}$ & $35 \mathrm{~min}$ & $30 \mathrm{~min}$ & 5 \\
\hline J3: Scenario for steady steaming & 20 minute & $30 \mathrm{~min}$ & $30 \mathrm{~min}$ & $40 \mathrm{~min}$ & $37 \mathrm{~min}$ & 2 \\
\hline 4: Scenario for approaching harbour & 20 minute & $35 \mathrm{~min}$ & $35 \mathrm{~min}$ & $35 \min$ & $35 \min$ & 3 \\
\hline 5: Scenario for finishing with engine & 15 minute & $25 \mathrm{~min}$ & $30 \mathrm{~min}$ & $35 \mathrm{~min}$ & $30 \mathrm{~min}$ & 3 \\
\hline $\begin{array}{c}\text { J6: Scenario for operation of } \\
\text { AUX.BOILERS and Cargo Turbines } \\
\end{array}$ & 30 minute & $35 \mathrm{~min}$ & $30 \mathrm{~min}$ & $35 \mathrm{~min}$ & $35 \mathrm{~min}$ & 4 \\
\hline
\end{tabular}

Table 3 Table 3Relations Between Achievement Time and Number of Errors Private Cadet

\begin{tabular}{|l|c|c|c|c|c|c|}
\hline \multicolumn{1}{|c|}{$\begin{array}{c}\text { Cadet Private Engineer } \\
\text { 1: Scenario for preparing for getting } \\
\text { underway }\end{array}$} & time standard & $\begin{array}{l}\text { group } \\
\text { 1 }\end{array}$ & $\begin{array}{l}\text { group } \\
2\end{array}$ & $\begin{array}{l}\text { group } \\
3\end{array}$ & $\begin{array}{l}\text { group } \\
4\end{array}$ & $\begin{array}{c}\text { Number } \\
\text { of error }\end{array}$ \\
\hline Scenario for manouvering to open sea & 30 minute & $20 \mathrm{~min}$ & $42 \mathrm{~min}$ & $35 \mathrm{~min}$ & $30 \mathrm{~min}$ & 5 \\
\hline C3: Scenario for steady steaming & 20 minute & $30 \mathrm{~min}$ & $30 \mathrm{~min}$ & $40 \mathrm{~min}$ & $37 \mathrm{~min}$ & 2 \\
\hline 4: Scenario for approaching harbour & 20 minute & $35 \mathrm{~min}$ & $35 \mathrm{~min}$ & $35 \mathrm{~min}$ & $35 \mathrm{~min}$ & 2 \\
\hline 5: Scenario for finishing with engine & 15 minute & $25 \mathrm{~min}$ & $30 \mathrm{~min}$ & $35 \mathrm{~min}$ & $30 \mathrm{~min}$ & 2 \\
\hline $\begin{array}{c}\text { C6: Scenario for operation of } \\
\text { AUX.BOILERS and Cargo Turbines }\end{array}$ & 30 minute & $35 \mathrm{~min}$ & $30 \mathrm{~min}$ & $35 \mathrm{~min}$ & $35 \mathrm{~min}$ & 1 \\
\hline
\end{tabular}

Table 4 Relations Between Achievement Time and Number of Errors Operasional Senior Engineer/ATT II

\begin{tabular}{|l|c|c|c|c|c|c|}
\hline & & & & & $\begin{array}{c}\text { NUMBER } \\
\text { OF } \\
\text { ERROR }\end{array}$ \\
\hline ANAGEMENT SENIOR ENGINEER & Passing grade score & grup1 & grup 2 & grup 3 & grup 4 & 5 \\
\hline MLS1: Scenario fouling and wear & 70 & 65 & 60 & 65 & 55 & 5 \\
\hline S2: Scenario combustion performance & 70 & 60 & 55 & 60 & 60 & 2 \\
\hline -S3: Scenario control loop optimizing & 70 & 50 & 65 & 45 & 65 & 4 \\
\hline -S4: Scenario heat balance/recovery & 70 & 45 & 45 & 55 & 45 & 2 \\
\hline MLS5: Scenario variable pitch & 70 & 50 & 50 & 50 & 50 & 1 \\
\hline MLS6: Scenario external condition & 70 & 55 & 65 & 45 & 50 & 3 \\
\hline
\end{tabular}

Table 5 Relations Between Achievement Time and Number of Errors Operasional Senior Engineer/ATT II 


\begin{tabular}{|c|c|c|c|c|c|}
\hline OPERSIONAL SENIOR ENGINEER & Passing grade score & group 1 & group 2 & group 3 & group 4 \\
\hline $\begin{array}{c}\text { OLS1: Scenario for failures and } \\
\text { emergency }\end{array}$ & 70 & 65 & 60 & 65 & 50 \\
\hline $\begin{array}{c}\text { OLS2: Scenario for team training } \\
\text { OLS3: Scenario for fault diagnosis and } \\
\text { tracking }\end{array}$ & 70 & 60 & 65 & 60 & 45 \\
\hline OLS4: Scenario crisis management & 70 & 50 & 50 & 50 & 50 \\
\hline $\begin{array}{c}\text { OLS5: Scenario restoring to normal } \\
\text { operation }\end{array}$ & 70 & 50 & 50 & 50 & 65 \\
\hline NUMBER OF ERROR & & 5 & 2 & 6 & 45 \\
\hline
\end{tabular}

Table 6 Relations Between Achievement Time and Number of Errors Management Senior Engineer/ATT I

The relation does not indicate a clear correspondence between score and the number of errors. As for the method of assessment, checking both score and errors ratio. The result of this study also indicates the necessity of checking both for the assessment of the training.

\begin{tabular}{|c|c|c|}
\hline$\pi n-4$ & Dopedion Eover - & Donotiond \\
\hline $1200=4$ & 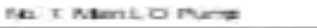 & Dowat \\
\hline $13 \times 00=4$ & 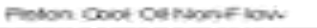 & matrisal \\
\hline 1200 & MenLoinaral & Nares \\
\hline $12=0 \times 4$ & 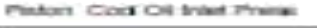 & maver \\
\hline$+3 \times 20,=4$ & 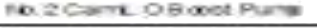 & Reury \\
\hline $1 \geq x=1$ & 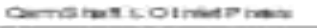 & Handera \\
\hline $12=0$ & 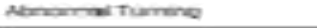 & Abouras \\
\hline t3xer of & Nomotres Tumeng & ntomnar \\
\hline$z=x=04$ & Turere Ca & $\mathrm{mex}$ \\
\hline raserat & Masscator Coad & Doend \\
\hline tares sy & Exotal & ond \\
\hline $1 \geq 5-4$ & 7urere mench & Ext \\
\hline
\end{tabular}

Table 7 Operation Record (history data)

\begin{tabular}{|l|c}
\hline Kind of the errors & Number of errors \\
\hline Ommission of Operation & 43 \\
\hline Extra opration & 50 \\
\hline Mistake of operational sequence & 22 \\
\hline Forgetting of operation confirmation & 17 \\
\hline Repetition of the same operation & 10 \\
\hline Others & 8 \\
\hline Total & 150 \\
\hline
\end{tabular}

Table 8 Contents of Operational by incompetence Cadet and Junior Engineer, ATT III/II/I 


\begin{tabular}{|c|c}
\hline Details of errors & Number of cases \\
\hline A preliminary pump is started & 20 \\
\hline When the pump is started, a neccessary valve is not opened & 15 \\
\hline $\begin{array}{c}\text { The operation order of the turning of the main engine is } \\
\text { reverse }\end{array}$ & 10 \\
\hline Heating of diesel oil & 13 \\
\hline $\begin{array}{c}\text { A closing failure of the steam valve for heating cooling fresh } \\
\text { water }\end{array}$ & 135 \\
\hline
\end{tabular}

Table 9 Specific Operation Error

The purpose of simulator training of the marine engine plant is to acquire procedural knowledge that is to know the present situation of the machinery plant and the preparatory operation for the next step. The data, in this case, will mainly be the history of operational procedure for the operation.

For example, in the case of transferring of fuel oil in the tank to the other, the very necessary thing is to find out whether fuel oil is in the tank or not and how the condition of tank is (as to condition of outlet valve). If the tank is in the state of readiness for fuel oil transfer, then the tank for fuel oil acceptance has to be checked before the start of transfer pump. The history of the operational procedure thus is consisted of confirmation of condition and operational procedure of machinery. The purpose of the data collection is to look into the operational error to specify the cause of such error from out of such history.

The data collection in AGB and Kongsberg Simulator was made onto its fourth-grade trainee Cadet, junior, operational and management level engineer. Operational data were collected from 10 trainees who experienced simulator training for around 4 hours.

The contents of data were about 25 sheets steps operational procedures for the starting of the main engine in the marine engine room. The trainee operates machines and valves on the screen graphics simulating an engine room by means of a mouse (as shown in Figure 1).Main engine remote operation is made on the screen graphics of a control panel (as shown in Figure 2). There is also a screen simulating engine room fuel oil system. As for the operational history of the trainee, operations of start/stop of pumps are stored in the PC as operational history. Such data were collected by local area network. Data samples are shown in Table 1 comprising operational hours, contents of operation, machinery equipment and conditions at alarm.

The trainee makes various kinds of errors during their operation before achieving goals. Table 2 shows the number of errors made by the trainee known from operational history.The errors show a tendency of 2 polarization. 5 trainees made only 5 errors and it is assumed that they followed the anticipated operational procedures. Meanwhile, the trainee who made 14 errors or more were assumed to have had difficulties in following the anticipated operational procedures and they were in a mess as to finding the operational procedure and repeated same procedures damaging machinery and equipment seriously. 


\begin{tabular}{|l|l|l|}
\hline \multicolumn{1}{|c|}{ Time } & \multicolumn{1}{|c|}{ Operational Equipment } & \multicolumn{1}{|c|}{ Condition } \\
\hline $13: 50: 44$ & No. 1 Main L O Pump & Run \\
\hline $13: 50: 44$ & Piston Cool Oil Non Flow & Normal \\
\hline $13: 50: 44$ & Main L O Inlet Press & Normal \\
\hline $13: 50: 44$ & Piston Cool Oil Inlet Press & Run \\
\hline $13: 50: 46$ & No. 2 Cam L O Boost Pump & Normal \\
\hline $13: 50: 46$ & Cam Shaft L O Inlet Press & Run \\
\hline $13: 50: 50$ & No. 1 Main Cool F W Pump & Normal \\
\hline $13: 50: 50$ & Cool F W Inlet Press & Abnormal \\
\hline $13: 51: 03$ & Abnormal Turning & Normal \\
\hline $13: 51: 05$ & Abnormal Turning & Disengage \\
\hline $13: 52: 04$ & Turning Gear & Open \\
\hline $13: 52: 32$ & Indocator Cock & On \\
\hline $13: 52: 50$ & Priming & Run \\
\hline $13: 53: 12$ & Turning Motor & \\
\hline
\end{tabular}

Table 10 Operation record (History data)

The assessment of the result of simulator training for the trainee was made based on the achievement time and the number of errors. Figure 3 shows the actual relations between the achievement time and the number of errors.

\begin{tabular}{|c|c|c|c|}
\hline Number of errors & Number of student & Number of errors & Number of student \\
\hline 5 & 5 & 11 & 5 \\
\hline 6 & 5 & 12 & 5 \\
\hline 7 & 5 & 13 & 5 \\
\hline 8 & 5 & 14 & 5 \\
\hline 9 & 5 & 15 & 5 \\
\hline 10 & 5 & 17 & 5 \\
\hline
\end{tabular}

Table 11Number of errors and the number of students

The relation in Figure 3 does not indicate a clear correspondence between the achievement time and the number of errors. Some trainees consumed short time for achievement but made many errors. As for the method of assessment,checking both the achievement time and errors ratio. The result of this study also indicates the necessity of checking both for the assessment of the training, Contents of Operational Errors by incompetence Trainee engineer, Study was made as to what kind of operational errors occurred during the training by the PC based ERS. The unskilled trainee finds difficulties in making systematical operation and in knowing the intention of the operation, which lead to the operational error eventually. The error of this kind is called behavior error easily distinguishable from outside and is classified as appearing error., In order to consider the training technique and a method of instruction in the training using the simulator, the contents of errors by the trainee was examined after the practice. Since it is difficult to build a plan of the operation in case of some of beginners, judging the present state and intention of operation are difficult for them to be able to understand. Therefore, this operational error is classified into the error of the external level so-called the error of easily observable behavior The kind of the errors and its number are shown in Table 13. 


\begin{tabular}{|l|c|}
\hline \multicolumn{1}{|c|}{ Kind of the errors } & Number of errors \\
\hline Omission of operation & 63 \\
\hline Extra operation & 60 \\
\hline Mistake of operaional sequence & 24 \\
\hline Forgetting of operation confirmation & 11 \\
\hline Repetition of the same operation & 9 \\
\hline Others & 6 \\
\hline Total & 173 \\
\hline
\end{tabular}

Table 12 Classification of error

some error's cases, the meaning of "stand by" was not clear to the trainee and he started the standby pump, too. This error occurred in all pumping systems that have main and standby pumps. Some errors occurred by wrong operation of valves. Operational errors occurred sometimes because the pumps are far apart on the screen and their operations were forgotten. All such errors indicate that systematical confirmation alter the starting of machinery is forgotten. Many errors on the simulator occurred due to poor handling of mouse.

\begin{tabular}{|l|c|}
\hline \multicolumn{1}{|c|}{ Details of errors } & Number of case \\
\hline A preliminary pump is started & 40 \\
\hline When the pump is started, a necessary valve is not open & 22 \\
\hline The operation order of the turning of the main engine is reverse & 12 \\
\hline Heating of diesel oil & 11 \\
\hline A closing failure of the steam valve for heating cooling fresh water & 11 \\
\hline
\end{tabular}

Table 13 Specific operation error

Unleashing cadets from the burden of the curriculum and allowing cadets to focus on big concepts empowers cadets to follow interests, seek connections, reformulate ideas and reach unique conclusions. Information is an individual interpretation. Learning and assessment process is not easy to manage because it is not visible I propose an idea / proposed merging learning process between Senior cadet (post marine practice / Semester VIII) and Junior cadet (pre-marine practice / Semester IV). The activity is for practice learning. The Department of Nautical uses the Bridge Simulator, and the Technical Department uses Engine Room Simulator. The learning process is combined between nautical and technical. This program is called integrated bridge engine simulator. They are divided into small groups consisting of 10 people per group. And the composition of each group consists of 5 Senior Cadet and 5 Youth Cadet persons to practice the duty on Bridge Simulator (Nautical Department) and Engine Room Simulator (Technical Department). Previously, each group we have practiced / taught with a predetermined scenario for practice in each simulator. In the final stages, all groups will take the practice test (assessment). Assessment criteria for graduation are scores of 70 and above, and with safe conditions (no collisions, runoff, or trouble / black out machines) and duration of execution are also recorded for each group. And this activity we race, so there is a healthy competition between them. The winners are the group that gets the highest score, safe condition, and the fastest duration of 
implementation. Subsequently, the winning groups of each major are awarded rewards. Provide examples of the real interactions that you show in improving the quality of student activities and the benefits of activities for both your institution students and others involved. Interaction with students In the implementation of integrated bridge engine simulator activities that have been described previously, that each group we have trained/guided to practice a predetermined scenario. Furthermore, if there are groups who feel still less smooth, then we give the group a chance to repractice outside the schedule, Then the end of all the test group, where the stage: initial briefing, scenario implementation, and debriefing. At the time of debriefing, comments will be given about the course of the scenario that has been practiced, and evaluate the error records that have been done, so that it does not happen again later. And members of the group may inquire about evaluating the implementation of their scenarios

\subsection{Operation of Main Engine Turning Gear}

Most of the errors in the turning operation of the main engine occur in the operational procedure because the mental model of the turning gear is not established. Operation is made only by its arrangement on the CBT without paying attention to the procedure, Operation of Jacket cooling Heating System, Error in the operation of heating system occurs because of the lack of conceptual knowledge of fuel oil heating and of wrong timing of heating. For an appropriate operation of the system, both procedural knowledge and conceptual knowledge are required. Error in forgetting steam valve closing is also observed. This is because attention is not paid to the temperature change of the jacket cooling. Such errors indicate the necessity of education on the changing condition of system after the operation of individual equipment. Sufficient explanation and instruction as to the use of the monitor are considered essential. The instructor has to teach checking the condition change of the marine engine plant after operation, Reaction to Alarm by incompetence Trainee, Operation by the incompetence trainee engineer is highlighted at the time of sounding alarmed. When the alarm is made by a wrong operational procedure, the incompetence trainee engineer tends to repeat the same procedure from the beginning. For example, when the turning motor is started while the indicator cock is closed, alarm of abnormal turning is made automatically. The incompetence trainee, without trying to find the reason for the operational error, tends to simply repeat the same procedure until he realizes the operational error and corrects it. This type of human error is human error in judgment. Our study on how the incompetence trainee engineer reacts to the alarm shows that the same operation is repeated 2.5 times on average. When the alarm is made, trainee concentrates his attention not to make alarm and stops the turning to escape from the alarm. Knowledge to find the cause of error is considered insufficient. Some kind of support system that helps the unskilled trainee assume the cause of error would be necessary for addition to the simple alarming of the system abnormality. Moreover, instructor not only teaches procedural knowledge but has to teach about the acquisition method of the information demanded in order to make the right judgment.

The behavior of incompetence Trainee Engineer During Operation, In order to characterize the features of the incompetence trainee engineer, their operation was recorded by videotape. Some wrong operations which do not appear in the operational data list are as follows:

Opening all the valves, Opening the valves from top to bottom, Opening the valves in a direction from left to right, No operation of the indicated equipment, Making mistake in the timing 
of valve opening of the starting air system, Making mistake in the operational sequence of main engine in the control room, Analysis of essential. It is easy to acquire conceptual knowledge such as structure of machinery etc. in the classroom teaching, but that is not enough for actual operation of the machinery. Junior engineers are required to have more information on the condition of the pumps to run or to stand-by. Such knowledge, which is usually acquired through the experience in the sea, can also be acquired through self-learning by a simulator. When the knowledge by selflearning is not sufficient, it must be supplemented by the instructor. The acquisition of knowledge by the coordination of self-learning and instructor is most important.

\subsection{Acquisition of Knowledge on the System}

Junior engineers understand the name and the function of machinery and equipment to be operated, but they often fail to understand the combination of machinery and equipment and its meaning. It may sometimes turn out that the valve near the pump is recognized and operated but the valve far from the pump is forgotten and not operated.

Typical examples of the lack of systematical knowledge are that they open all the valves and/or they open the valves in a direction from right to left on the screen. Since the simulator can put the marine engine plant as an energy flow on the screen, it will be quite necessary to show them the system for their understanding.

\subsection{Enhancement of Judgment Skill.}

When the junior engineers are required to make some decision during the operation of the simulator, they are liable to operate the machinery with wrong judgment or to continue it without any judgment because they are short of knowledge necessary for judging criteria. When the judgment is required, the criteria for judgment have to be shown to them. In some cases, they give up the operational failing in satisfying operating conditions. The instructor has to show them the conditions necessary to continue the operation.

a. Propose Solution (Recommendation)

b. Implemented Roles Lecture Constructiveness

c. Implemented Role of Model

d. Implemented Roles Lecture Constructiveness when assessment \& evaluation

Implemented Constructive learning Strategy: Building coordination and communication during the preparation of cadets of maritime industry character book, Monitoring progress of progress (progress),Establish agreement in accordance with the system of the maritime industry to be adopted

\subsection{Implemented Various Safety Scenario}




\begin{tabular}{|c|c|c|c|c|}
\hline \multirow[b]{2}{*}{ No } & \multirow[b]{2}{*}{ Time } & First Day & Second Day & Third Day \\
\hline & & CBT & $\begin{array}{l}\text { ENGINE ROOM } \\
\text { SIMULATOR }\end{array}$ & $\begin{array}{c}\text { ASSESMENT } \\
\text { Group 1, 2, 3, 4, } 5\end{array}$ \\
\hline 1 & $07.30-09.00$ & $\begin{aligned} \text { C1: } & \text { SCENARIO FOR } \\
& \text { PREPARING FOR } \\
& \text { GETTING } \\
& \text { UNDERWAY }\end{aligned}$ & $\begin{aligned} \text { C1: } & \text { SCENARIO FOR } \\
& \text { PREPARING FOR } \\
& \text { GETTING } \\
& \text { UNDERWAY }\end{aligned}$ & $\begin{array}{l}\text { C1: SCENARIO FOR } \\
\text { PREPARING FOR } \\
\text { GETTING } \\
\text { UNDERWAY }\end{array}$ \\
\hline 2 & $09.00-10.30$ & $\begin{aligned} \text { C2: } & \text { SCENARIO FOR } \\
& \text { MANOUVERING TO } \\
& \text { OPEN SEA }\end{aligned}$ & $\begin{aligned} \text { C2: } & \text { SCENARIO FOR } \\
& \text { MANOUVERING } \\
& \text { TO OPEN SEA }\end{aligned}$ & $\begin{aligned} \text { C2: }: & \text { SCENARIO FOR } \\
& \text { MANOUVERING TO } \\
& \text { OPEN SEA }\end{aligned}$ \\
\hline \multicolumn{5}{|c|}{ Coffee Break } \\
\hline 3 & $10.30-11.55$ & $\begin{aligned} \text { C3 : SCENARIO FOR } \\
\text { STEADY STEAMING }\end{aligned}$ & $\begin{aligned} \text { C3 : SCENARIO FOR } \\
\text { STEADY } \\
\text { STEAMING }\end{aligned}$ & $\begin{aligned} \text { C3 : SCENARIO FOR } \\
\text { STEADY STEAMING }\end{aligned}$ \\
\hline \multicolumn{5}{|c|}{ Lunch Time } \\
\hline 4 & $13.00-14.30$ & $\begin{aligned} \text { C4: } & \text { SCENARIO FOR } \\
& \text { APPROACHING } \\
& \text { HARBOUR }\end{aligned}$ & $\begin{aligned} \text { C4: } & \text { SCENARIO FOR } \\
& \text { APPROACHING } \\
& \text { HARBOUR }\end{aligned}$ & $\begin{aligned} \text { C4: } & \text { SCENARIO FOR } \\
& \text { APPROACHING } \\
& \text { HARBOUR }\end{aligned}$ \\
\hline 5 & $14.30-15.30$ & $\begin{array}{l}\text { C5 : SCENARIO FOR } \\
\text { FINISHING WITH ENGINE }\end{array}$ & $\begin{aligned} \text { C5: } & \text { SCENARIO FOR } \\
& \text { FINISHING WITH } \\
& \text { ENGINE }\end{aligned}$ & $\begin{aligned} \text { C5 : } & \text { SCENARIO FOR } \\
& \text { FINISHING WITH } \\
& \text { ENGINE }\end{aligned}$ \\
\hline \multicolumn{5}{|c|}{ Coffee Break } \\
\hline 6 & $15.45-17.00$ & $\begin{aligned} & \text { C6: }: \text { SCENARIO FOR } \\
& \text { OPERATION OF } \\
& \text { AUX.BOILERS AND } \\
& \text { CARGO TUBINES }\end{aligned}$ & $\begin{aligned} \text { C6: } & \text { SCENARIO FOR } \\
& \text { OPERATION OF } \\
& \text { AUX.BOILERS } \\
& \text { AND CARGO } \\
& \text { TUBINES }\end{aligned}$ & $\begin{aligned} \text { C6 : } & \text { SCENARIO FOR } \\
& \text { OPERATION OF } \\
& \text { AUX.BOILERS AND } \\
& \text { CARGO TUBINES }\end{aligned}$ \\
\hline
\end{tabular}

Table 14grand Design Run Down Standard Activities Engine Simulator Training Program Engine Cadet D.Iv Stip/Private/Junior Engineer Jakarta

Description :

For this study, we have 20 Cadet Engineer undergoing Course in Engine Simulator Program. At First Day all member cadet engineer will attend CBT (Computer Based Training) with Material consist :
C1 : SCENARIO FOR PREPARING FOR GETTING UNDERWAY
C2 : SCENARIO FOR MANOUVERING TO OPEN SEA
C3 : SCENARIO FOR STEADY STEAMING
C4 : SCENARIO FOR APPROACHING HARBOUR
C5 : SCENARIO FOR FINISHING WITH ENGINE
C6 : SCENARIO FOR OPERATION OF AUX.BOILERS AND CARGO TUBINES 


\begin{tabular}{|c|c|c|c|c|c|}
\hline \multirow[b]{2}{*}{ Time } & First Day & Second Day & Third Day & Fourth day & Fifth Day \\
\hline & CBT & $\begin{array}{l}\text { ENGINE ROOM } \\
\text { SIMULATOR }\end{array}$ & CBT & $\begin{array}{l}\text { ENGINE ROOM } \\
\text { SIMULATOR }\end{array}$ & $\begin{array}{c}\text { ASSESMENT } \\
\text { Group } 1,2,3,4,5\end{array}$ \\
\hline $\begin{array}{l}07.30- \\
09.00\end{array}$ & $\begin{array}{l}\text { OLS1 : SCENARIO } \\
\text { FOR FAILURES } \\
\text { AND EMERGENCY }\end{array}$ & $\begin{array}{c}\text { OLS1 : SCENARIO } \\
\text { FOR } \\
\text { FAILURES } \\
\text { AND } \\
\text { EMERGENCY }\end{array}$ & $\begin{array}{l}\text { OLS } 1 \text { : SCENARIO } \\
\text { FOR FAILURES } \\
\text { AND EMERGENCY }\end{array}$ & $\begin{array}{l}\text { OLS1: } \\
\text { SCENARIO } \\
\text { FOR } \\
\text { FAILURES } \\
\text { AND } \\
\text { EMERGENC } \\
\text { Y } \\
\end{array}$ & $\begin{array}{l}\text { OLS1 : SCENARIO } \\
\text { FOR FAILURES } \\
\text { AND } \\
\text { EMERGENCY }\end{array}$ \\
\hline $\begin{array}{l}09.00- \\
10.30\end{array}$ & $\begin{array}{c}\text { OLS2 }: \text { SCENARIO } \\
\text { FOR TEAM } \\
\text { TRAINING }\end{array}$ & $\begin{array}{c}\text { OLS2 }: \text { SCENARIO } \\
\text { FOR TEAM } \\
\text { TRAINING }\end{array}$ & $\begin{array}{c}\text { OLS2 : SCENARIO } \\
\text { FOR TEAM } \\
\text { TRAINING }\end{array}$ & $\begin{array}{c}\text { OLS2: } \\
\text { SCENARIO FOR } \\
\text { TEAM } \\
\text { TRAINING }\end{array}$ & $\begin{array}{c}\text { OLS2 : SCENARIO } \\
\text { FOR TEAM } \\
\text { TRAINING }\end{array}$ \\
\hline \multicolumn{6}{|c|}{ Coffee Break } \\
\hline $\begin{array}{l}10.30- \\
11.55\end{array}$ & $\begin{array}{l}\text { OLS3 : SCENARIO } \\
\text { FOR FAULT } \\
\text { DIAGNOSIS AND } \\
\text { TRACKING }\end{array}$ & $\begin{array}{l}\text { OLS3 : SCENARIO } \\
\text { FOR FAULT } \\
\text { DIAGNOSIS AND } \\
\text { TRACKING }\end{array}$ & $\begin{array}{c}\text { OLS3 : SCENARIO } \\
\text { FOR FAULT } \\
\text { DIAGNOSIS AND } \\
\text { TRACKING }\end{array}$ & $\begin{array}{c}\text { OLS3: } \\
\text { SCENARIO FOR } \\
\text { FAULT } \\
\text { DIAGNOSIS } \\
\text { AND TRACKING }\end{array}$ & $\begin{array}{l}\text { OLS3 : SCENARIO } \\
\text { FOR FAULT } \\
\text { DIAGNOSIS AND } \\
\text { TRACKING }\end{array}$ \\
\hline \multicolumn{6}{|c|}{ Lunch Time } \\
\hline $\begin{array}{c}13.00- \\
14.30\end{array}$ & $\begin{array}{c}\text { OLS4 }: \text { SCENARIO } \\
\text { CRISIS } \\
\text { MANAGEMENT }\end{array}$ & $\begin{array}{c}\text { OLS4 : SCENARIO } \\
\text { CRISIS } \\
\text { MANAGEMENT }\end{array}$ & $\begin{array}{c}\text { OLS4 : SCENARIO } \\
\text { CRISIS } \\
\text { MANAGEMENT }\end{array}$ & $\begin{array}{l}\text { OLS4: } \\
\text { SCENARIO } \\
\text { CRISIS } \\
\text { MANAGEMENT }\end{array}$ & $\begin{array}{c}\text { OLS4 : SCENARIO } \\
\text { CRISIS } \\
\text { MANAGEMENT }\end{array}$ \\
\hline $\begin{array}{l}14.30- \\
15.30\end{array}$ & $\begin{array}{c}\text { OLS5 :SCENARIO } \\
\text { RESTORING TO } \\
\text { NORMAL } \\
\text { OPERATION } \\
\end{array}$ & $\begin{array}{c}\text { OLS5 :SCENARIO } \\
\text { RESTORING TO } \\
\text { NORMAL }\end{array}$ & $\begin{array}{c}\text { OLS5 :SCENARIO } \\
\text { RESTORING TO } \\
\text { NORMAL }\end{array}$ & $\begin{array}{l}\text { OLS5:SCENARI } \\
\text { O RESTORING } \\
\text { TO NORMAL }\end{array}$ & $\begin{array}{c}\text { OLS5 :SCENARIO } \\
\text { RESTORING TO } \\
\text { NORMAL } \\
\end{array}$ \\
\hline
\end{tabular}

DESCRIPTION:

For this study we have 20 persons Operational level Senior Engineer undergoing Course in Engine Simulator Program.

At First Day all member cadet engineer will attend CBT (Computer Base Training) with Material consist :

OLS1 : SCENARIO FOR FAILURES AND EMERGENCY
OLS2 : SCENARIO FOR TEAM TRAINING
OLS3 : SCENARIO FOR FAULT DIAGNOSIS AND TRACKING
OLS4 : SCENARIO CRISIS MANAGEMENT
OLS5 :SCENARIO RESTORING TO NORMAL OPERATION

@ Second days attend CBT (Computer Base Training) with Materi consist :

OLS1 : SCENARIO FOR FAILURES AND EMERENCY

OLS2 : SCENARIO FOR TEAM TRAINING

OLS3 : SCENARIO FOR FAULT DIAGNOSIS AND TRACKING

OLS4 : SCENARIO CRISIS MANAGEMENT

OLS5 :SCENARIO RESTORING TO NORMAL OPERATION

@ 3th and 4th Day Practice at Engine Simulator with material Consist :

OLS1 : SCENARIO FOR FAILURES AND EMERENCY

OLS2 : SCENARIO FOR TEAM TRAINING

OLS3 : SCENARIO FOR FAULT DIAGNOSIS AND TRACKING

OLS4 : SCENARIO CRISIS MANAGEMENT

OLS5 :SCENARIO RESTORING TO NORMAL OPERATION

@ 5th Day Assessment at Engine Room Simulator Group 1,2,3,4,5 with materiel Consist :

OLS1 : SCENARIO FOR FAILURES AND EMERENCY

OLS2 : SCENARIO FOR TEAM TRAINING

OLS3 : SCENARIO FOR FAULT DIAGNOSIS AND TRACKING

OLS4 : SCENARIO CRISIS MANAGEMENT 
OLS5 :SCENARIO RESTORING TO NORMAL OPERATION

\begin{tabular}{|c|c|c|c|c|c|}
\hline \multirow[b]{2}{*}{ Time } & First Day & Second Day & Third Day & Fourth day & Fifth Day \\
\hline & CBT & $\begin{array}{c}\text { ENGINE ROOM } \\
\text { SIMULATOR }\end{array}$ & CBT & $\begin{array}{c}\text { ENGINE ROOM } \\
\text { SIMULATOR }\end{array}$ & $\begin{array}{c}\text { ASSESMENT } \\
\text { Group } 1,2,3,4,5\end{array}$ \\
\hline $\begin{array}{c}07.30- \\
09.00\end{array}$ & $\begin{array}{l}\text { MLS 1: SCENARIO } \\
\text { FOULING AND } \\
\text { WEAR }\end{array}$ & $\begin{array}{c}\text { MLS } 1 \text { : SCENARIO } \\
\text { FOULING } \\
\text { AND WEAR }\end{array}$ & $\begin{array}{l}\text { MLS } 1 \text { : SCENARIO } \\
\text { FOULING AND } \\
\text { WEAR }\end{array}$ & $\begin{array}{l}\text { MLS 1: } \\
\text { SCENARIO } \\
\text { FOULING } \\
\text { AND WEAR }\end{array}$ & $\begin{array}{c}\text { MLS } 1 \text { : SCENARIO } \\
\text { FOULING AND } \\
\text { WEAR }\end{array}$ \\
\hline $\begin{array}{c}09.00- \\
10.30\end{array}$ & $\begin{array}{l}\text { MLS } 2 \text { : SCENARIO } \\
\text { COMBUSTION } \\
\text { PERFOMANCE }\end{array}$ & $\begin{array}{l}\text { MLS } 2 \text { : SCENARIO } \\
\text { COMBUSTION } \\
\text { PERFOMANCE }\end{array}$ & $\begin{array}{l}\text { MLS } 2 \text { : SCENARIO } \\
\text { COMBUSTION } \\
\text { PERFOMANCE }\end{array}$ & $\begin{array}{l}\text { MLS 2: } \\
\text { SCENARIO } \\
\text { COMBUSTION } \\
\text { PERFOMANCE }\end{array}$ & $\begin{array}{l}\text { MLS } 2 \text { : SCENARIO } \\
\text { COMBUSTION } \\
\text { PERFOMANCE }\end{array}$ \\
\hline \multicolumn{6}{|c|}{ Coffee Break } \\
\hline $\begin{array}{c}10.30- \\
11.55\end{array}$ & $\begin{array}{l}\text { MLS } 3 \text { : SCENARIO } \\
\text { CONTROL LOOP } \\
\text { OPTIMIZING }\end{array}$ & $\begin{array}{l}\text { MLS } 3 \text { : SCENARIO } \\
\text { CONTROL LOOP } \\
\text { OPTIMIZING }\end{array}$ & $\begin{array}{l}\text { MLS } 3 \text { : SCENARIO } \\
\text { CONTROL LOOP } \\
\text { OPTIMIZING }\end{array}$ & $\begin{array}{l}\text { MLS } 3 \text { : } \\
\text { SCENARIO } \\
\text { CONTROL LOOP } \\
\text { OPTIMIZING }\end{array}$ & $\begin{array}{l}\text { MLS } 3 \text { : SCENARIO } \\
\text { CONTROL LOOP } \\
\text { OPTIMIZING }\end{array}$ \\
\hline \multicolumn{6}{|c|}{ Lunch Time } \\
\hline $\begin{array}{c}13.00- \\
14.30\end{array}$ & $\begin{array}{l}\text { MLS } 4 \text { : SCENARIO } \\
\text { HEAT BALANCE / } \\
\text { RECOVERY }\end{array}$ & $\begin{array}{l}\text { MLS } 4 \text { : SCENARIO } \\
\text { HEAT BALANCE / } \\
\text { RECOVERY }\end{array}$ & $\begin{array}{l}\text { MLS } 4 \text { : SCENARIO } \\
\text { HEAT BALANCE / } \\
\text { RECOVERY }\end{array}$ & $\begin{array}{l}\text { MLS 4: } \\
\text { SCENARIO } \\
\text { HEAT } \\
\text { BALANCE / } \\
\text { RECOVERY }\end{array}$ & $\begin{array}{l}\text { MLS } 4 \text { : SCENARIO } \\
\text { HEAT BALANCE / } \\
\text { RECOVERY }\end{array}$ \\
\hline $\begin{array}{c}14.30- \\
15.30\end{array}$ & $\begin{array}{l}\text { MLS } 5 \text { : SCENARIO } \\
\text { VARIABLE PITCH }\end{array}$ & $\begin{array}{l}\text { MLS } 5 \text { : SCENARIO } \\
\text { VARIABLE PITCH }\end{array}$ & $\begin{array}{l}\text { MLS } 5 \text { : SCENARIO } \\
\text { VARIABLE PITCH }\end{array}$ & $\begin{array}{l}\text { MLS 5: } \\
\text { SCENARIO } \\
\text { VARIABLE } \\
\text { PITCH }\end{array}$ & $\begin{array}{l}\text { MLS } 5 \text { : SCENARIO } \\
\text { VARIABLE PITCH }\end{array}$ \\
\hline \multicolumn{6}{|c|}{ Coffee Breake } \\
\hline $\begin{array}{c}15.45- \\
17.00\end{array}$ & $\begin{array}{l}\text { MLS } 6 \text { : SCENARIO } \\
\text { EXTERNAL } \\
\text { CONDITION }\end{array}$ & $\begin{array}{l}\text { MLS 6: SCENARIO } \\
\text { EXTERNAL } \\
\text { CONDITION }\end{array}$ & $\begin{array}{l}\text { MLS 6: SCENARIO } \\
\text { EXTERNAL } \\
\text { CONDITION }\end{array}$ & $\begin{array}{l}\text { MLS 6: } \\
\text { SCENARIO } \\
\text { EXTERNAL } \\
\text { CONDITION }\end{array}$ & $\begin{array}{l}\text { MLS } 6: \text { SCENARIO } \\
\text { EXTERNAL } \\
\text { CONDITION }\end{array}$ \\
\hline
\end{tabular}

Table 15 SENIOR ENGINEER /ATT 1 STIP JAKARTA

\section{DESCRIPTION:}

For this study, we have 20 Management level Senior Engineer undergoing Course in Engine Simulator Program.

At First\& 2nd Day all member cadet engineer will attend CBT (Computer Based Training ) with Material consist :

MLS 1 : SCENARIO FOULING AND WEAR

MLS 2 : SCENARIO COMBUSTION PERFOMANCE

MLS 3 : SCENARIO CONTROL LOOP OPTIMIZING

MLS 4 : SCENARIO HEAT BALANCE / RECOVERY

MLS 5 : SCENARIO VARIABLE PITCH

MLS 6 : SCENARIO EXTERNAL CONDITION

@3rd \& 4th Day Practice at Engine Simulator with Material Consist :

MLS 1 : SCENARIO FOULING AND WEAR

MLS 2 : SCENARIO COMBUSTION PERFOMANCE

MLS 3 : SCENARIO CONTROL LOOP OPTIMIZING

MLS 4 : SCENARIO HEAT BALANCE / RECOVERY

MLS 5 : SCENARIO VARIABLE PITCH

MLS 6 : SCENARIO EXTERNAL CONDITION

@ 5th Day Assessment at Engine Room Simulator Group 1,2,3,4,5 with Material Consist : MLS 1 : SCENARIO FOULING AND WEAR

MLS 2 : SCENARIO COMBUSTION PERFOMANCE 


\section{MLS 3 : SCENARIO CONTROL LOOP OPTIMIZING \\ MLS 4 : SCENARIO HEAT BALANCE / RECOVERY \\ MLS 5 : SCENARIO VARIABLE PITC \\ MLS 6 : SCENARIO EXTERNAL CONDITION}

The benefit of activities, The benefits of integrated bridge engine simulator activity is to measure the extent to which the absorption of theories and practices that have been previously taught. Because this activity is comprehensive, covering multiple / cross-learning at once. So the evaluation results of this activity can be followed up, which lessons are less, and what lessons are enough. And of course must involve Lecturers of each department, so that each lecturer concerned can follow up the results of this evaluation in the face of the next semester.

This will improve the quality of learning continuously, and in turn, will improve the quality of the training graduates themselves.

says that knowledge is non-objective, temporary, constantly changing, and uncertain. Some things that get attention constructive learning, namely: prioritizes real learning in the relevant context, prioritize the process, inculcate learning in the context of social experience, learning is done in an effort to construct experience.

Constructivism, one of the schools of knowledge philosophy that is the result of its own construction. The process of knowledge formation goes on and on and there is always a reorganization or reconstruction because of a new understanding Knowledge cannot be moved away from the brain of lecturer to student's brain. Constructivism in the learning process Learning to form meaning Learning is the process of developing thinking by making new insights. The learning process takes place at the time of the scheme of someone who stimulates further thought. Learning outcomes are influenced by cadets with the physical world and the environment and depending on what the cadets know. Some things that get attention constructivist learning, prioritizing real learning in the relevant context prioritize the process of instilling the learning in the context of the learning social experience done in an effort to construct the experience.

\section{Conclusion}

PC based ERS support incompetency engineer trainee,Need implementing constructivism learning process \& Role Play, model ,There is no correspondence between time for achievement and the number of errors,Educational support by instructor will be indispensable for the correction of such insufficiency and the instructor not only teaches the knowledge of fundamental operation procedure but has to teach the checking criteria for normal operation or abnormal operation.

\section{References}

[1] K. Ikenishi, "Application of Personalized System of Instruction to Education and Training Using ERS based on PC," in The Japan Instruction of Marine Engineering Conference, 2003, pp. 81-84.

[2] C. Kogo, "An Application of Personalized System of Instruction (PSI) to University," Comput. Educ., vol. 7, pp. 117-122, 1999.

[3] T. Nakamura and Y. Arimoto, "An Engine Room Simulator for Education," J. Japan Mar. Eng. Soc., vol. 22, no. 6, pp. 379-387, 1987. 
[4] T. Matsuo, "The motivation model for prevention of human-errors by external cue," $J$. Hum. Interface Soc., vol. 5, no. 1, pp. 75-83, 2003.

[5] S. Bang and K. Furuta, "Operator's Knowledge Model and Ability to Handle Abnormal Situations," J. Hum. Interface Soc., vol. 6, no. 1, pp. 13-118, 2004.

[6] E. Hollnagel, Human Reliability Analysis-Context and Control. Academic Press, 1993. 